\title{
The Comparison of the Microbiological Characteristics of Wet Dough and Dry Powder Tarhana's and Evaluation of Possible Health Risks
}

\author{
Nesrin İçli ${ }^{1, a, *}$, Fevziye Işsl Kesbiç̧, \\ ${ }^{1}$ Department of Nutrition and Dietetics, Faculty of Health Sciences, Kastamonu University, 37150 Kastamonu, Turkey \\ ${ }^{2}$ Application and Research Center, Center Research Laboratory, Kastamonu University,37150 Kastamonu, Turkey
} *Corresponding author

\section{A R T I C L E I N F O A B S T R A C T}

Research Article

Tarhana is a traditional food produced by different traditional methods and the materials used in production are changing from a region to another region. The total yeast and molds, total mesophilic aerobic bacteria, Escherichia Coli and enterococci bacteria count of wet dough Kastamonu tarhana and dry powdered tarhana samples were investigated in this study. All microorganisms examined

Received : 30/11/2021

Accepted : 20/12/2021 in our study were detected in one of the wet dough tarhana samples. The highest total yeast and molds, total mesophilic aerobic bacteria, Escherichia coli and enterococci bacteria counts were determined for the wet dough tarhana samples to be $2.2 \times 10^{6}, 6.6 \times 10^{7}, 1.2 \times 10^{6}$ and $1.9 \times 10^{6} \mathrm{cfu} / \mathrm{g}$, respectively. No growth of microorganism capable of reproduction was observed in the powdered tarhana produced industrially. In addition, the Escherichia coli and enterococci bacteria were not detected for any of the dry powder tarhana samples. It was seen that the microbial load of the wet tarhana produced at home in Kastamonu was higher than the powdered tarhana. The reason for this situation was thought to be due to poor production and hygiene conditions. The presence of Escherichia coli and enterococci bacteria in samples indicates that there is possible fecal contamination of the raw materials used in wet dough tarhana production. Electron microscope images of molds obtained in our study are similar to molds producing mycotoxins. These results show that the wet dough tarhana have a greater risk for microorganism development and human health compared to dry powder tarhana.

Keywords:

Pathogen bacteria

Mold

Mycotoxin

SEM

\section{Introduction}

Tarhana is a very popular traditional Turkish fermented cereal food and consumed in large quantities especially in rural areas. Besides that, there are some food products similar to tarhana in other countries, which are called different names such as "tahonyaltakuna" (Hungary), "talkkuna" (Finland), "trahana" (Greece), "atole" (Scotland), "kishk" (Syria, Jordan and Egypt), "kushuk" (Iraq) (Kabak and Dobson 2011; Uçar and Çakiroğlu, 2011; Özçam et al., 2014; Arslan-Tontul et al., 2018). Although various vegetables, herbs and spices are used in different proportions in the production of tarhana, cereal products such as wheat flour and yoghurt are indispensable ingredients (Özçam et al., 2014; Kaymak et al., 2019). It is usually produced at home, but it is also one of the leading commercially produced instant soups. The desired ingredients are made into dough, and this dough is fermented for 1-7 days with yeast and lactic acid bacteria (LAB). Then the fermented dough is dried under the sun (domestic production) or with a hot air dryer (industrial production) and pulverized (Kivanc and Funda, 2017; Kaymak et al., 2019). Powdered tarhana can be stored for a long time and consumed as a soup (Ibanoğlu et al., 1999; Arslan-Tontul et al., 2018). In some regions of Turkey, it can be spread as a thin layer and dried in the form of chips, and it can be consumed as a tortilla (Kaymak et al., 2019), or sometimes it can be consumed wet without drying (Arslan-Tontul et al., 2018).

Tarhana is a source of protein, vitamins and minerals resulting from its ingredients and has a very high nutritional value (Daglioglu, 2000; Özdemir et al., 2007; Kivanc and Funda, 2017). Since the drying process significantly reduces the LAB and yeast numbers, the consumption of wet tarhana is better than dried tarhana in terms of nutritional value (Erbaş et al., 2005; Arslan-Tontul et al., 2018). In the Kastamonu city, fermented tarhana dough is consumed wet without drying. This tarhana dough is fermented by occasionally mixing with dill and basil stalks for a few weeks. Then the dough is taken into storage 
containers such as glass jars and stored in the refrigerator. However, due to its high-water activity, the storage period for wet tarhana is limited to 6 months in the refrigerator (Erbaş et al., 2005), and if it is produced without complying with hygiene rules, contamination and microbial growth may threaten human health. Since the ingredients used in its production are uncooked, the most important risk factors that Tarhana may contain are lack of pasteurization, use of contaminated raw materials and poorly controlled fermentation conditions (Daglioglu et al., 2002; Uçar and Çakiroğlu, 2011). In addition, contamination of ingredients is an important source of mycotoxins at every stage of production and up to consumption (Kaymak et al., 2019). Although there are studies examining the effects of different production techniques on tarhana properties, a limited number of studies examining tarhana in terms of microbiology have been carried out (Kivanc and Funda, 2017). Moreover, microbiological changes in the fermentation process and after drying of tarhana produced in the laboratory were discussed, and the total mesophilic aerobic bacteria (TMAB), total yeast and mold (TYM) and lactic acid bacteria (LAB) counts were examined in general (Erbaş et al., 2005; Karagozlu et al., 2008; Settanni et al., 2011; Donmez, 2015; Özel, 2015; Kivanc and Funda, 2017; Arslan-Tontul et al., 2018; Kaya and Şimşek, 2020). For this reason, TMAB, TYM, Escherichia coli (E. coli) and enterococci bacteria (EB) count of wet dough tarhana samples from Kastamonu city and dried powder tarhana samples were investigated and samples taken from TYM colonies cultured from wet dough tarhana were examined under an electron microscope. Finally, wet dough Kastamonu tarhana and powder tarhana were compared in terms of hygiene, contamination and health risks by evaluating the results obtained from this study.

\section{Materials and Methods}

\section{Sample Collection}

Five Kastamonu wet dough tarhana samples, which are produced at home with the traditional method, were purchased from the villagers who were selling in the bazaars established in Kastamonu city centre. Three homemade powdered dry tarhanas were obtained from shops selling homemade products from different regions, and one industrially produced powdered dry tarhana sample was obtained from a chain market in the Kastamonu city. All of the samples were obtained in $1 \mathrm{~kg}$ jars and two pieces of each. While one of each sample pair was kept in the refrigerator at $+2-8^{\circ} \mathrm{C}$ until analysis, the others were kept at room temperature with their lids tightly closed for five days in order not to lose their moisture.

\section{Sample Preparation}

$10 \mathrm{~g}$ of sample was transferred to $90 \mathrm{ml}$ of $0.1 \%$ peptone water (Merck Millipore, Darmstadt, Germany) and homogenized with a blender. Serial decimal dilutions were prepared from this solution to a dilution of $10^{-6}$ by the addition of peptone water (Şengün et al., 2009).

\section{Materials}

Plate Count Agar (PCA) (Merck 1.05463, Darmstadt, Germany), Membrane-filter Enterococcus Selective Agar acc. to SLANETZ and BARTLEY (Merck 1.05262), Eosin
Methylene-blue Lactose Sucrose Agar (EMB) (Merck 1.01347), Potato Dextrose Agar (PDA) (Merck 1.10130) were used as media in the study.

\section{Methods}

Colony counting was performed using the surface plating technique for all microbiologic assays of tarhana samples and aliquots $(0.1 \mathrm{~mL})$ of each serial dilution were inoculated by spreading over the agar plates. PCA was used for TMAB analysis and incubated for 48 hours at $30^{\circ} \mathrm{C}$ (TS EN ISO 4833-2, 2014). Membrane-filter Enterococcus Selective Agar acc. to Slanetz and Bartley was used for EB analysis and incubated at $37^{\circ} \mathrm{C}$ for 24 hours (Lachica and Hartman, 1968). E. coli was incubated for 24 hours at $35^{\circ} \mathrm{C}$ using EMB for assays (Nys et al., 2004). PDA was used for TYM analysis and incubated at $20^{\circ} \mathrm{C} \mathrm{C}$ for five days (TS ISO 21527-2, 2014). Colonies on agar plates were counted at the end of the incubation time, and the number of colonies forming units (cfu) per $\mathrm{g}$ was calculated. Agar plates containing less than 300 colonies were used for colony counting (TS EN ISO 4833-2, 2014). Nuve En 120 (Turkey) incubator was used in incubation processes. Moisture contents of all tarhana samples were determined by drying 5-gram pieces of samples in a drying oven (Protech - PLF/PKD, Norway) at $130 \pm 5^{\circ} \mathrm{C}$ for 2 hours (TS EN ISO 712, 2012). For the measurement of $\mathrm{pH}$, the sample and distilled water were mixed $(1: 9$, w/v) by vortex (Velp Sci. Classic, Italy) until a homogeneous mixture was obtained, the $\mathrm{pH}$ was then measured by $\mathrm{pH}$ meter (ISOLAB - Laborgerate $\mathrm{GmbH}$, Germany). Electron microscope images of samples taken from colonies obtained from yeast-mold incubation were taken with a scanning electron microscope (SEM) (FEI Quanta FEG 250, USA) located in Kastamonu University Central Research Laboratory Application and Research Center.

\section{Results and Discussion}

The results of microbiological and moisture analysis of tarhana are given in Table 1. and Table 2., respectively. The microorganism examined in this study were found in one of the doughs tarhana's from Kastamonu city (sample coded with K1). In addition, TYM and TMAB growth were detected in all wet dough tarhanas. The highest TYM, TMAB, E. coli and EB counts were determined for the Kastamonu dough tarhana samples to be $2.2 \times 10^{6}$ (sample coded with K1), $6.6 \times 10^{7}$ (sample coded with K4), 1.2×106 (sample coded with K1) and $1.9 \times 10^{6}$ (sample coded with $\mathrm{K} 1$ ) cfu/g, respectively (Table 1 ). While no microorganism capable of reproduction growth $\left(<10^{2} \mathrm{cfu} / \mathrm{g}\right)$ was observed from industrially produced powdered dry tarhana, TYM and TMAB growth were observed in homemade powdered dry tarhana from Zonguldak province and only TMAB was detected at a minimum level $\left(1 \times 10^{2} \mathrm{cfu} / \mathrm{g}\right)$ in homemade powdered dry tarhana originating from Afyon and Uşak. In addition, E. coli and EB growth was not observed $\left(<10^{2}\right.$ $\mathrm{cfu} / \mathrm{g})$ in any of the powdered dry tarhana samples. TMAB and EB counts of tarhana samples which the tests carried out after the samples were kept at room temperature for 5 days were found to decrease compared to the results of the samples stored at $+2-8^{\circ} \mathrm{C}$, possibly due to $\mathrm{pH}$ decreasing during storage (Erbaş, 2005). However, an increase in TYM counts was observed, possibly due to the good 
growth of molds even at low $\mathrm{pH}$ values thanks to high water activities (Gödek et al., 2021). In the literature review, only a few studies were found in which homemade tarhana was examined microbiologically (Coşkun, 1996; Soyyiğit, 2004; Uçar and Çakiroğlu, 2011; Özdemir et al., 2012); Gülbandılar et al., 2014); Hendek Ertop et al., 2019). Coşkun (1996) found the maximum number of microorganisms to be 60000 units/g and the TYM number to be between 0-52000 units/g in homemade tarhana collected from Trakya and its region. Coliform bacteria were not found in any of the 51 tarhana samples he examined. Soyyiğit (2004) also examined 27 homemade tarhana produced in Isparta and its region, and the TMAB is $1.4 \times 10^{3}-2.1 \times 10^{7} \mathrm{cfu} / \mathrm{g}$ and the TYM is $<10-3.3 \times 10^{7}$ $\mathrm{cfu} / \mathrm{g}$. Uçar and Çakıroğlu (2011) examined the homemade tarhanas obtained from the province of Ankara microbiologically and observed that 8 out of 20 samples (one at $10^{2} \mathrm{cfu} / \mathrm{g}$, six at $10^{3} \mathrm{cfu} / \mathrm{g}$ and one at $10^{4} \mathrm{cfu} / \mathrm{g}$ ) contained mesophilic aerobic bacteria growth. Again, they detected $10^{3}-10^{2} \mathrm{cfu} / \mathrm{g}$ Staphylococcus growth in two of 20 samples, yeast and mold growth between $10^{2}$ and $10^{3} \mathrm{cfu} / \mathrm{g}$ in five samples, and $10^{2}-10^{3} \mathrm{cfu} / \mathrm{g}$ Bacillus cereus growth in three samples. They observed no E. coli, coliform or Salmonella contamination in any of the investigated samples. Özdemir, Alkan and Çon (2012) stored wet tarhana from Kastamonu city for 4 months and at the end of the storage, Lactobacillus spp. number increased by 0.96 $\log$ to $5.24 \log \mathrm{cfu} / \mathrm{g}$; Lactococcus spp. count increased by $0.74 \log$ to $5.07 \log \mathrm{cfu} / \mathrm{g}$; TYM count increased by 0.75 $\log$ to $5.25 \log \mathrm{cfu} / \mathrm{g}$; The number of TMAB also increased by $0.40 \log$ to $5.16 \mathrm{log} \mathrm{cfu} / \mathrm{g}$. The numbers of Staphylococcus aureus, coliform group microorganisms and $E$. coli, which were below the countable level in the post-production analyzes of the samples, were also determined below the countable level at the end of the storage period. In a study conducted in Gediz and Kütahya region, TMAB count in homemade tarhana was found in the range of $1.5 \times 10^{2}-2.5 \times 10^{2} \mathrm{cfu} / \mathrm{g}$, and Staphylococcus aureus, E. coli, Salmonella sp., Shigella sp., Bacillus cereus, Enterococcus faecalis, Clostridium sp. not detected (Gülbandılar et al., 2014). Hendek Ertop, Cerit and Atasoy (2019) in their study, detected $10^{3}-10^{6} \mathrm{cfu} / \mathrm{g}$ yeast, $10^{3}-10^{6}$ $\mathrm{cfu} / \mathrm{g}$ aerobic $\mathrm{LAB}$ and $10^{5}-10^{6} \mathrm{cfu} / \mathrm{g}$ anaerobic LAB in wet dough Kastamonu tarhana samples. They also stated that wet tarhana carries more microbial load than dry tarhana. In the studies of Özdemir et al. and Hendek Ertop et al. unlike our study, no microbiological comparison of homemade Kastamonu wet dough tarhanas with powdered dry tarhanas was made, nor electron microscopy examination of samples taken from yeast and mold cultivation. In these two studies, EB examination is also not seen. Moreover, in our study, samples taken from PDA medium containing yeast and mold were examined by SEM and the images obtained are given in Figure 1. TYM colony color in PDA was yellow, and electron microscope images showed conidiophores and conidial heads, which resembled molds such as aspergillus and penicillium rather than yeast. In the study by Kıvanç and Funda (2017), yeasts determined during tarhana fermentation were Kluyveromyces marxianus, Yarrowia lipolytica, Pichia membranaefaciens, Pichia mexicana, Pichia angusta, Debaryomyces hansenii, Candida sorboxylosa, Candida fluviatilis, Saccharomyces cerevisiae. Electron microscope images of Saccharomyces Cerevisiae differ from the images in our study. The yeast cell is typically about five to ten micrometers in diameter and buds can be easily selected in the images as the cells proliferate through a process called budding (Karimy, et al., 2020) Electron microscope images of other yeasts (Kluyveromyces marxianus-Mehmood et al., 2018), (Yarrowia lipolyticaApte et al., 2013), (Pichia membranaefaciens-Kurtzman, 2011), (Debaryomyces hansenii-Kreger-van $\mathrm{Rij}$ and Veenhuis, 1975) determined in tarhana in the study of Kıvanç and Funda are not similar to the images obtained in our study. Mycotoxins are natural toxins with low molecular weight and a wide variety of chemical structures, which are formed as a result of secondary metabolism of fungal (mold) genera such as Aspergillus, Penicillium, Fusarium, Alternaria and Claviceps. These products are extremely toxic, most of them carcinogens, teratogens, mutagens (Sabuncuoğlu et al., 2008). Aspergillus flavus colonies are seen on PDA agar as yellow to green/granular. This species is microscopically characterized by conidiophores that are globose vesicles bearing chains of conidia and conidial heads are typically radiate figüre (Shekhany and Rostam, 2016). The electron microscope images obtained in our study are similar to those described in the above sentence. Penicillium species also have conidiophores and conidia similar to those in our study (Visagie et al., 2014). There are also studies that determine aflatoxin, which can be produced by Aspergillus species, and ochratoxin, which can be produced by Penicillium species in various tarhanas (Özçam et al., 2014; Kaymak et al., 2019).

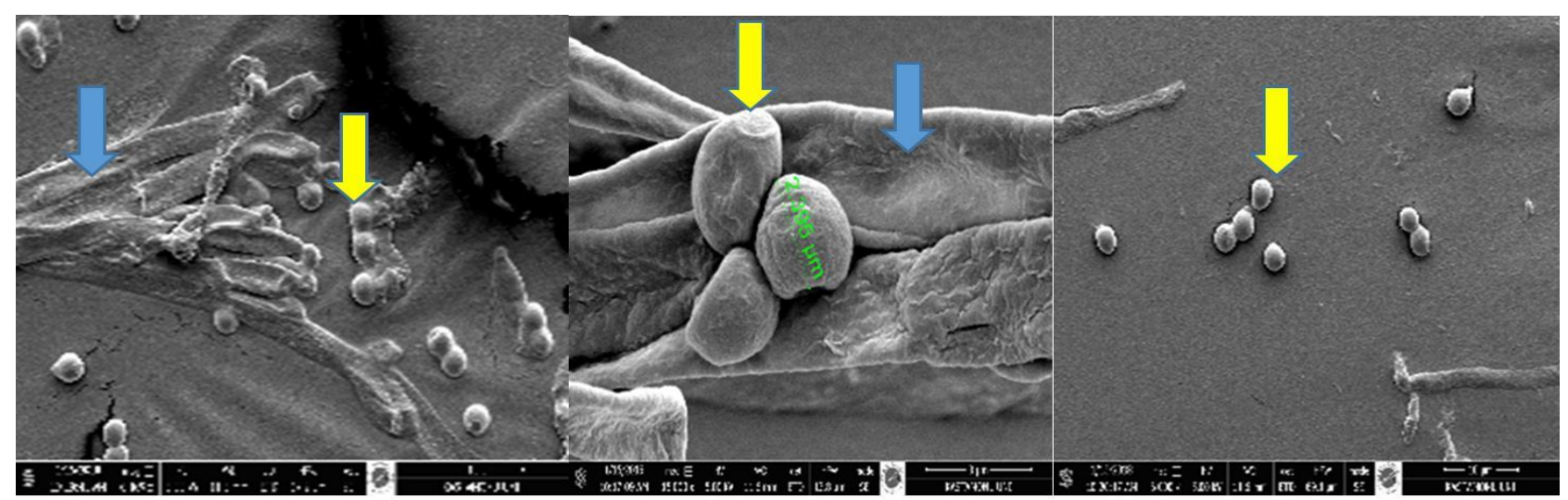

Figure 1. Scanning electron micrographs showing molds on PDA. The blue arrows mean shriveled conidiophore. The yellow arrows mean conidial heads or conidiospore. 
Table 1. The microbiological analysis results of this study.

\begin{tabular}{|c|c|c|c|c|c|}
\hline \multirow{11}{*}{ Stored at $+4-8 \mathrm{C}$} & \multirow{2}{*}{ Sample Code } & \multicolumn{2}{|r|}{ TYM } & \multicolumn{2}{|c|}{ TMAB } \\
\hline & & $\mathrm{Cfu} / \mathrm{g}$ & $\mathrm{Cfu} / \mathrm{g}$ on $\mathrm{DW}$ & $\mathrm{Cfu} / \mathrm{g}$ & $\mathrm{Cfu} / \mathrm{g}$ on DW \\
\hline & K1 & $2.2 \times 10^{6}$ & $4 \times 10^{6}$ & $2.8 \times 10^{6}$ & $5.1 \times 10^{6}$ \\
\hline & $\mathrm{K} 2$ & $7.2 \times 10^{5}$ & $1.4 \times 10^{6}$ & $4.4 \times 10^{7}$ & $8.5 \times 10^{7}$ \\
\hline & K3 & $1.1 \times 10^{5}$ & $2 \times 10^{5}$ & $1.8 \times 10^{6}$ & $3.3 \times 10^{6}$ \\
\hline & K4 & $1 \times 10^{5}$ & $1.8 \times 10^{5}$ & $6.6 \times 10^{7}$ & $1.2 \times 10^{8}$ \\
\hline & K5 & $7.3 \times 10^{5}$ & $1.4 \times 10^{6}$ & $1.2 \times 10^{6}$ & $2.2 \times 10^{6}$ \\
\hline & $\mathrm{Z}$ & $3.5 \times 10^{5}$ & $4 \times 10^{5}$ & $2.5 \times 10^{5}$ & $2.9 \times 10^{5}$ \\
\hline & $\mathrm{U}$ & $<10^{2}$ & $<10^{2}$ & $1 \times 10^{2}$ & $1 \times 10^{2}$ \\
\hline & A & $<10^{2}$ & $<10^{2}$ & $1 \times 10^{2}$ & $1 \times 10^{2}$ \\
\hline & I & $<10^{2}$ & $<10^{2}$ & $<10^{2}$ & $<10^{2}$ \\
\hline \multirow{9}{*}{ Strored at room temperatature for 5 days } & K1 & $1.9 \times 10^{6}$ & $3.5 \times 10^{6}$ & $2.5 \times 10^{6}$ & $4.5 \times 10^{6}$ \\
\hline & $\mathrm{K} 2$ & $9.5 \times 10^{6}$ & $1.8 \times 10^{7}$ & $1 \times 10^{7}$ & $1.9 \times 10^{7}$ \\
\hline & K3 & $1.7 \times 10^{6}$ & $3.1 \times 10^{6}$ & $3.7 \times 10^{5}$ & $6.8 \times 10^{5}$ \\
\hline & K4 & $3.4 \times 10^{6}$ & $6.2 \times 10^{6}$ & $2.7 \times 10^{7}$ & $5 \times 10^{7}$ \\
\hline & K5 & $1.6 \times 10^{6}$ & $3 \times 10^{6}$ & $1 \times 10^{7}$ & $1.9 \times 10^{7}$ \\
\hline & $\mathrm{Z}$ & $4.6 \times 10^{5}$ & $5.3 \times 10^{5}$ & $1 \times 10^{2}$ & $1 \times 10^{2}$ \\
\hline & $\mathrm{U}$ & $<10^{2}$ & $<10^{2}$ & $<10^{2}$ & $<10^{2}$ \\
\hline & A & $<10^{2}$ & $<10^{2}$ & $<10^{2}$ & $<10^{2}$ \\
\hline & $\mathrm{I}$ & $<10^{2}$ & $<10^{2}$ & $<10^{2}$ & $<10^{2}$ \\
\hline \multirow{11}{*}{ Stored at $+4-8 C$} & \multirow{2}{*}{ Sample Code } & \multicolumn{2}{|c|}{ E. coli } & \multicolumn{2}{|r|}{ EB } \\
\hline & & $\mathrm{Cfu} / \mathrm{g}$ & $\mathrm{Cfu} / \mathrm{g}$ on DW & $\mathrm{Cfu} / \mathrm{g}$ & $\mathrm{Cfu} / \mathrm{g}$ on DW \\
\hline & K1 & $1.2 \times 10^{6}$ & $2.2 \times 10^{6}$ & $1.9 \times 10^{6}$ & $3.5 \times 10^{6}$ \\
\hline & $\mathrm{K} 2$ & $<10^{2}$ & $<10^{2}$ & $4.9 \times 10^{5}$ & $9.5 \times 10^{5}$ \\
\hline & K3 & $<10^{2}$ & $<10^{2}$ & $<10^{2}$ & $<10^{2}$ \\
\hline & K4 & $<10^{2}$ & $<10^{2}$ & $<10^{2}$ & $<10^{2}$ \\
\hline & K5 & $<10^{2}$ & $<10^{2}$ & $<10^{2}$ & $<10^{2}$ \\
\hline & $\mathrm{Z}$ & $<10^{2}$ & $<10^{2}$ & $<10^{2}$ & $<10^{2}$ \\
\hline & $\mathrm{U}$ & $<10^{2}$ & $<10^{2}$ & $<10^{2}$ & $<10^{2}$ \\
\hline & A & $<10^{2}$ & $<10^{2}$ & $<10^{2}$ & $<10^{2}$ \\
\hline & I & $<10^{2}$ & $<10^{2}$ & $<10^{2}$ & $<10^{2}$ \\
\hline \multirow{9}{*}{ Strored at room temperatature for 5 days } & K1 & $1.3 \times 10^{6}$ & $2.4 \times 10^{6}$ & $1.7 \times 10^{5}$ & $3.1 \times 10^{5}$ \\
\hline & $\mathrm{K} 2$ & $<10^{2}$ & $<10^{2}$ & $1.2 \times 10^{5}$ & $2.3 \times 10^{5}$ \\
\hline & K3 & $<10^{2}$ & $<10^{2}$ & $<10^{2}$ & $<10^{2}$ \\
\hline & K4 & $<10^{2}$ & $<10^{2}$ & $<10^{2}$ & $<10^{2}$ \\
\hline & K5 & $<10^{2}$ & $<10^{2}$ & $<10^{2}$ & $<10^{2}$ \\
\hline & $\mathrm{Z}$ & $<10^{2}$ & $<10^{2}$ & $<10^{2}$ & $<10^{2}$ \\
\hline & $\mathrm{U}$ & $<10^{2}$ & $<10^{2}$ & $<10^{2}$ & $<10^{2}$ \\
\hline & A & $<10^{2}$ & $<10^{2}$ & $<10^{2}$ & $<10^{2}$ \\
\hline & $\mathrm{I}$ & $<10^{2}$ & $<10^{2}$ & $<10^{2}$ & $<10^{2}$ \\
\hline
\end{tabular}

Cfu/g: Colony forming unit/gram sample, DW: Dry weight, K: Dough tarhana from Kastamonu, Z: Powder tarhana from Zonguldak, U: Powder tarhana from Uşak, A: Powder tarhana from Afyon, I: Industrially produced packaged powder tarhana

Table 2. Average moisture content of tarhana samples.

\begin{tabular}{l|c}
\hline \multicolumn{1}{c|}{ Sample Code } & Moisture content \% $(\mathrm{w} / \mathrm{w}) \pm \mathrm{SD}$ \\
\hline K1 & $45.28 \pm 0.02$ \\
K2 & $48.40 \pm 0.01$ \\
K3 & $45.69 \pm 0.02$ \\
K4 & $45.45 \pm 0.03$ \\
K5 & $46.50 \pm 0.00$ \\
Z & $12.55 \pm 0.03$ \\
U & $10.58 \pm 0.02$ \\
A & $4.73 \pm 0.04$ \\
I & $5.44 \pm 0.03$ \\
\hline SD: Standart deviation, K: Dough tarhana from Kastamonu, Z: Powder tarhana from Zonguldak, U: Powder tarhana from Ușak, A: Powder tarhana
\end{tabular}
from Afyon, I: Industrially produced packaged powder tarhana

It is accepted that food products with high TMAB and TYM counts are not produced and preserved under hygienic conditions. The limits of TMAB and TYM counts are specified in the TS 2282 Tarhana standard (2004), and all of the wet dough tarhanas obtained from Kastamonu city and powdered dry tarhana from Zonguldak city, which we examined in our study, do not comply with this standard. E. coli is one of the facultative anaerobic bacteria that persist in the flora of the large intestine (Turgut, 2021). Therefore, the presence of E. coli in water and food 
indicates possible fecal contamination, and the presence of corresponding intestinal pathogens causes various infectious diseases (Arslan and Özdemir, 2013). Enterococci are the dominant flora of the digestive system of humans and animals, but are also found in soil, surface waters, plants, vegetables and insects. Enterococci are among the most common nosocomial pathogens, especially Enterococcus faecium and Enterococcus faecalis are opportunistic pathogens, in addition to bacteremia and endocarditis, it has been reported that it can cause infections in the urinary system and tissues such as the central nervous system. It has been stated that resistance to some antibiotics such as vancomycin and their various virulence factors play an important role in the pathogenicity mechanisms of enterococci (Isleroglu et al., 2008). The growth of both $E$. coli and EB in the K1 coded wet dough tarhana sample, and the EB growth in the K2 coded wet dough tarhana sample, is an indication that these tarhanas were contaminated by feces. The reason for this contamination may be the mixing of sewage into the water used in tarhana production, or the use of vegetables and spices grown by irrigation with sewage-contaminated water. These results show that the wet dough tarhanas from Kastamonu city (especially K1 and K2 coded samples) are produced under poor production conditions and hygienic rules are not followed. In addition, the moisture content (Table 2.) of wet dough tarhanas and powder tarhanas originating from Zonguldak and Uşak are not in accordance with the TS 2282 Tarhana standard (2004) (moisture limit 10\%, m/m), and the high-water activity of these tarhanas has been seen as the main reason for their microorganism growth susceptibility. The reason why the powdered tarhana of Zonguldak contains higher amount of moisture than other powdered tarhana may be that the drying efficiency is poor due to the low number of sunny days and humid air in the Black Sea region. Although the humidity in Uşak tarhana is above $10 \%$, the lack of significant microorganism growth is thought to be due to the high amount of spices it contains, especially the hot chili pepper. Zonguldak tarhana contains almost no spices, as supportive evidence.

In our study, it was seen that the microbial load of the wet tarhana produced at home in Kastamonu was higher than the powdered tarhana, and this was thought to be due to poor production and hygiene conditions. In fact, the presence of samples with E. coli and EB indicates that there is a possible fecal contamination of the raw materials used in tarhana production. These results shown that the wet dough tarhana samples have a greater risk of microorganism development and human health. Electron microscope images of molds obtained in our study are similar to molds producing mycotoxins, and their identification is planned with a further study. In addition, it is thought that people who produce at home should be informed about the proper and correct production and hygiene conditions with the cooperation of authorized institutions and organizations in terms of public health.

\section{Acknowledgement}

We would like to thank Kastamonu University Central Research Laboratory Application and Research Center for their assistance in our study. A part of the study was presented as a poster at the 4th International Symposium on Traditional Foods from Adriatic to Caucasus Congress and only the abstract was published in the proceedings.

\section{Conflict of Interest}

The author declares that there is no conflict of interest.

\section{References}

Apte M, Sambre D, Gaikawad S, Joshi S, Bankar A, Kumar AR, Zinjarde S. 2013. Psychrotrophic yeast Yarrowia lipolytica NCYC 789 mediates the synthesis of antimicrobial silver nanoparticles via cell-associated melanin. Amb Express, 3(1): 1-8. doi: 10.1186/2191-0855-3-32

Arslan S, Özdemir F. 2013. Investigation of Escherichia coli O157 in Turkish homemade white cheese. European Journal of Biology, 72(1): 45-51.

Arslan-Tontul S, Mutlu C, Candal C, Erbaş M. 2018. Microbiological and chemical properties of wet tarhana produced by different dairy products. Journal of Food Science and Technology, 55(12): 4770-4781. doi: 10.1007/s13197018-3410-9

Kurtzman CP. 2011. Pichia EC. Hansen 1904, In: Cletus P. Kurtzman, Jack W. Fell, Teun Boekhout (editors), The Yeasts (Fifth Edition) Chapter 57. Elsevier. pp. 685-707. ISBN: 9780444521491 (online) https://doi.org/10.1016/B978-0444-52149-1.00057-4

Coşkun F. 1996. Research on the chemical, microbiological and sensory properties of home tarhana produced in different regions of Thrace. MSc Thesis, Institute of Science, Trakya University, Tekirdag, Turkey.

Donmez M. 2015. Changes of some physicochemical and microbioiogical properties and fatty acids composition of tarhana during fermentation periods. Oxidation Communications, 38: 961-968.

Daglioglu O, Arıcı M, Konyalı M, Gümüş T. 2002. Effects of tarhana fermentation and drying methods on the fate of Escherichia coli 0157:H7 and Staphylococcus aureus. European Food Research and Technology, 215(6): 515-551. doi: 10.1007/s00217-002-0584-0

Erbaş M, Certel M, Uslu MK. 2005. Microbiological and chemical properties of Tarhana during fermentation and storage as wet-sensorial properties of Tarhana soup. LWTFood Science and Technology, 38(4): 409-416. doi: 10.1016/j.lwt.2004.06.009

Gödek Z, Mustafa N, Semerci AB, Tunç K. 2021. Determination of Microbial Quality of White Cheese That Sale in Sakarya Bazaars. ALKÜ Journal of Science, 3(1): 44-49. doi: 10.46740/alku.822781

Gülbandılar A, Dönmez M, Okur M, Çeliközlü S. 2014. Determination of chemical, microbiological and sensorial properties in Gediz tarhana, a traditional Turkish cereal food. Journal of Environmental Protection and Ecology, 15(3A): 1507-1516.

Hendek Ertop M, Cerit ZG, Atasoy R. 2019. Evaluation of physicochemical, nutritional and sensory properties of the wet tarhana. Food Science and Quality Management, 83: 6167. doi: 10.7176/FSQM

Ibanoglu S, Ibanoglu E, Ainsworth P. 1999. Effect of different ingredients on the fermentation activity in tarhana. Food Chemistry, 64: 103-106. doi: 10.1016/S03088146(98)00071-5

Isleroglu H, Yıldırım Z, Demirpençe Y, Yıldırım M. 2008. Enterococcus: Biochemical, Physiological and Functional Properties and pathogenicity. Academic Food Journal, 6(3): 16-26.

Kabak B, Dobson ADW. 2011. An introduction to the traditional fermented foods and beverages of Turkey. Critical Reviews in Food Science and Nutrition, 51: 248-260. doi: 10.1080/10408390903569640 
Karagozlu N, Ergonul B, Karagozlu C. 2008. Microbiological attributes of instant tarhana during fermentation and drying. Bulgarian Journal of Agricultural Science, 14(6): 535-541.

Karimy MF, Damayanti E, Suryani AE, Prasetyo E, Nurhayati R, Anwar M, Anggraeni AS. 2020. A simple method for analysis of Saccharomyces cerevisiae morphology by applying a high vacuum mode of the scanning electron microscopy and without chemical fixatives. In IOP Conference Series: Earth and Environmental Science, doi: https://doi.org $10.1088 / 1755-1315 / 462 / 1 / 012048$

Kaya HI, Şimşek Ö. 2020. Characterization of Pediococcus acidilactici PFC69 and Lactococcus lactis PFC77 Bacteriocins and Their Antimicrobial Activities in Tarhana Fermentation. Microorganisms, https://doi.org/10.3390/microorganisms8071083.

Kaymak T, Koca E, Atak M, Sarikaya E, Stroka J. 2019. Determination of aflatoxins and ochratoxin A in traditional turkish cereal-based fermented food by multi-affinity column cleanup and LC fluorescence detection: single-laboratory validation. Journal of AOAC International, 102(1): 156-163. doi: 10.5740/jaoacint.17-0490

Kivanc M, Funda EG. 2017. A functional food: a traditional Tarhana fermentation. Food Science and Technology, 37: 269-274. doi: 10.1590/1678-457X.08815

Kreger-van Rij NJW, Veenhuis M. 1975. Electron microscopy of ascus formation in the yeast Debaryomyces hansenii. Microbiology, 89(2): 256-264. doi: 10.1099/00221287-89-2256

Lachica RVF, Hartman PA. 1968. Two improved media for isolating and enumerating enterococci in certain frozen foods. Journal of Applied Bacteriology, 31(1): 151-156. doi: 10.1111/j.1365-2672.1968.tb00352.x

Mehmood N, Alayoubi R, Husson E, Jacquard C, Büchs J, Sarazin C, Gosselin I. 2018. Kluyveromyces marxianus, an attractive yeast for ethanolic fermentation in the presence of imidazolium ionic liquids. International Journal of Molecular Sciences, https://doi.org/10.3390/ijms19030887.

Nys S, Okeke IN, Kariuki S, Dinant GJ, Driessen C, Stobberingh EE. 2004. Antibiotic resistance of faecal Escherichia coli from healthy volunteers from eight developing countries. Journal of Antimicrobial Chemotherapy, 54(5): 952-955. doi: $10.1093 / \mathrm{jac} / \mathrm{dkh} 448$

Özçam M, Obuz E, Tosun H. 2014. Aflatoxin M1 in Tarhana chips. Food Additives and Contaminants: Part B, 7(3): 182185. doi: 10.1080/19393210.2013.874373

Özdemir N, Alkan LB, Çon AH. 2012. Microbiological Quality of Fresh and Stored Kastamonu Wet Tarhana. Alinteri Journal of Agriculture Science, 23(2): 35-40.

Özel S, Sabanoğlu S, Çon AH, Şimşek Ö. 2015. Diversity and stability of yeast species during the fermentation of tarhana. Food Biotechnology, 29(1): 117-129. doi: 10.1080/08905436.2014.996895

Sabuncuoğlu SA, Baydar T, Giray B, Şahin G. 2008. Mikotoksinler: toksik etkileri, degredasyonları, oluşumlarının önlenmesi ve zararlı etkilerinin azaltılması. Hacettepe University Journal of the Faculty of Pharmacy, (1): 63-92.
Sengun IY, Nielsen DS, Karapinar M, Jakobsen M. 2009. Identification of lactic acid bacteria isolated from Tarhana, a traditional Turkish fermented food. International Journal of Food Microbiology, 135(2): 105-111. doi: 10.1016/j.ijfoodmicro.2009.07.033

Settanni L, Tanguler H, Moschetti G, Reale S, Gargano V, Erten H. 2011. Evolution of fermenting microbiota in tarhana produced under controlled technological conditions. Food Microbiology, 28(7): 1367-1373. doi: 10.1016/j.fm.2011.06. 008

Shekhany KA, Rostam SR. 2016. Detection of Aflatoxigenic Aspergillus flavus in Maize Grains and Soils in Sulaimani Province using Molecular Approaches. Journal of Zankoy Sulaimani, 18: 25-36. doi:10.17656/jzs. 10557

Soyyiğit, H. 2004. Isparta ve yöresinde üretilen ev yapımı tarhanaların mikrobiyolojik ve teknolojik özellikleri. PhD Dissertation. Institute of Science, Süleyman Demirel University, Isparta, Turkey.

TSE, 2004. TS 2282. Tarhana standard. Available from: https://intweb.tse.org.tr/standard/standard/StandardAra.aspx [Accessed 08 November 2021]

TSE, 2012. TS EN ISO 712. Cereals and cereal products Determination of moisture content -Reference method. Available from: https://intweb.tse.org.tr/standard/standard/StandardAra.aspx [Accessed 08 November 2021]

TSE, 2014. TS EN ISO 4833-2. Microbiology of the food chain Horizontal method for the enumeration of microorganisms Part 2: Colony count at 30 degrees $\mathrm{C}$ by the surface plating technique. Available from: https://intweb.tse.org.tr/ standard/standard/StandardAra.aspx [Accessed 08 November 2021]

TSE, 2014. TS ISO 21527-2. Microbiology of food and animal feeding stuffs -- Horizontal method for the enumeration of yeasts and moulds -- Part 2: Colony count technique in products with water activity less than or equal to 0,95 . Available from: https://intweb.tse.org.tr/standard/standard/ StandardAra.aspx [Accessed 08 November 2021]

Turgut N. 2021. Escherichia Coli O157: H7 Prevalence and Control in Foods. Journal of Adnan Menderes University Health Sciences Faculty, 5(1): 101-114. doi: 10.46237/amusbfd.707281

Uçar A, Çakiroğlu FP. 2011. Comparison of some chemical and microbiological quality of homemade tarhana in Ankara, Turkey. Journal of Food, Agriculture and Environment, 9: 3437.

Visagie CM, Houbraken J, Frisvad JC, Hong SB, Klaassen, CHW, Perrone G, Samson RA. 2014. Identification and nomenclature of the genus Penicillium. Studies in mycology, 78: 343-371. doi: 10.1016/j.simyco.2014.09.001 